\title{
PENGARUH KONSUMSI TELUR AYAM RAS REBUS TERHADAP PENINGKATAN KADAR HB PADA IBU HAMIL TRIMESTER II DI BPM WILAYAH KERJA PUSKESMAS KLATEN TENGAH
}

\author{
Sugita, Supiati \\ Kementerian Kesehatan Politeknik Kesehatan Surakarta Jurusan Kebidanan
}

\begin{abstract}
Effect, Boiled Eggs, Pregnancy, Hemoglobin. The purpose of this study was to prove that Effect, Boiled Eggs, Pregnancy, Hemoglobin. To determine the effect of boiled eggs consumption to the increase of hemoglobin levels in second trimester of pregnancy in Puskesmas Klaten Tengah. This study used a quasi experimental research design with a non-randomized cotrol group pretest-posttest design. The population in this study were pregnant women in Puskesmas Klaten Tengah with 30 samples. Sampling using purposive sampling with 15 samples as the treatment group and 15 samples as a control group. Analysis of the data by independenty sample t-test. The hemoglobin levels change of the second trimester pregnant women between the pre and post boiled eggs consumption group and Fe tablet consumption group and non consumption showed $0.001(<0.05)$ of p value, it means that there has a differences on hemoglobin levels between the pre and post boiled eggs consumption group and Fe tablet consumption group and non consumption. Boiled eggs consumption are effective to increase hemoglobin levels in second trimester of pregnancy in Puskesmas Klaten Tengah.
\end{abstract}

Keywords: Effect, Boiled Eggs, Pregnancy, Hemoglobin.

Abstrak : Pengaruh, Telur Rebus, Kehamilan, Hemoglobin. Tujuan Penelitian ini adalah untuk mengetahui pengaruh konsumsi telur ayam ras rebus terhadap peningkatan kadar Hb pada ibu hamil trimester II di wilayah kerja Puskesmas Klaten Tengah. Jenis penelitian ini menggunakan quasi experiment dengan rancangan penelitian nonrandomized control group pretes-postest design. Populasi dalam penelitian ini adalah ibu hamil di wilayah kerja Puskesmas Klaten Tengah dengan 30 sampel. Pengambilan sampel menggunakan teknik purposive sampling dengan 15 sampel sebagai kelompok perlakuan dan 15 sampel sebagai kelompok kontrol. Analisa data dengan independenty sample t-test. Perubahan kadar $\mathrm{Hb}$ ibu hamil trimester II antara pre dan post konsumsi tablet Fe dengan konsumsi telur ayam ras rebus dan tanpa konsumsi telur ayam ras rebus menunjukkan $p$ value $0,001(<0,05)$, berarti terdapat perbedaan kadar $\mathrm{Hb}$ ibu hamil trimester II sebelum dan sesudah konsumsi tablet Fe antara kelompok dengan konsumsi telur ayam ras rebus dan kelompok tanpa konsumsi telur ayam ras rebus. Konsumsi telur ayam ras rebus efektif untuk peningkatan kadar $\mathrm{Hb}$ pada ibu hamil trimester II di wilayah kerja Puskesmas Klaten Tengah.

Kata Kunci : Pengaruh, Telur Rebus, Kehamilan, Hemoglobin 


\section{PENDAHULUAN}

Masa kehamilan merupakan suatu permulaan kehidupan baru dari periode pertumbuhan dan perkembangan janin. Keadaan ini berkaitan dengan kesehatan ibu sebelum hamil dan saat hamil, karena sebagai penentu status kesehatan bayinya di masa yang akan datang. Nutrisi adalah salah satu faktor yang mengpengaruhi hasil akhir suatu kehamilan. Apabila pemenuhan kebutuhan gizi selama kehamilan tidak tercukupi dapat menyebabkan plasenta sebagai media sumber nutrisi tidak mampu menyediakan makanan yang cukup bagi janin. Hal ini dapat menimbulkan berbagai komplikasi dalam kehamilan seperti berat badan lahir rendah, bayi lahir prematur, kelainan bawaan dan anemia pada ibu hamil (Manuba,2010).

Kandungan gizi telur kaya akan protein yang bermutu tinggi. Rata-rata kadar protein telur adalah $12-16 \%$ atau sekitar 7-8 gram protein dalam satu butir telur yang cukup besar. Di dalam telur juga ada kandungan sejenis meneral mikro yang sangat penting, yaitu zat besi, seng dan selenium. Telur mengandung zat besi yang cukup baik. Kandungan besi telur adalah 1,04 mg pada telur utuh dan 0,95 mg pada kuning telur. Sementara itu, kandungan zat seng pada telur adalah sebesar $0,72 \mathrm{mg}$ telur utuh dan $0,58 \mathrm{mg}$ kuning telur (Anwar dan Khomsan, 2009).

Ibu hamil trimester II yang mengkonsumsi tablet $\mathrm{Fe}$ dengan mengkonsumsi telur ayam ras rebus satu butir sehari pada pukul antara 16.00-20.00 WIB selama satu bulan, kenaikan kadar $\mathrm{Hb}$ akan lebih tinggi dibandingkan yang tidak mengkonsumsi telur ayam ras rebus.

Dengan adanya penelitian ini diharapkan dapat memberikan informasi kepada masyarakat tentang peningkatan kadar $\mathrm{Hb}$ pada ibu hamil trimester II yang mengalami anemia.

\section{METODE PENELITIAN}

Untuk membuktikan pengaruh konsumsi telur ayam ras rebus terhadap peningkatan kdar $\mathrm{Hb}$ pada ibu hamil trimester II, peneliti menggunakan jenis penelitian quasi experiment atau eksperimen semu pada ibu hamil di wilayah kerja Puskesmas Klaten Tengah. Pada eksperimen semu peneliti memberikan konsumsi telur ayam ras rebus pada ibu hamil trimester II satu butir sehari pada pukul antara 16.00 20.00 WIB setiap hari selama satu bulan(30 hari).

Eksperimen semu atau quasi experiment adalah desain penelitian yang tidak mempunyai pembatas yang ketat terhadap randomisasi, dan pada saat yang sama dapat mengontrol ancaman-ancaman validitas (Notoatmodjo, 2010)

Rancangan yang digunakan adalah non-equivalent control group atau disebut non-randomized control group pretestpostest design. Dalam rancangan ini, pengelompokan anggota sampel pada kelompok eksperimen dan kelompok control tidak dilakukan secara random atau acak (Notoatmodjo, 2010). Sampel pada penelitian ini diobservasi terlebih dahulu sebelum diberi perlakuan, kemudian setelah diberi perlakuan sampel tersebut diobservasi kembali (Hidayat, 2011).

\section{HASIL PENELITIAN}

Pada tabel 1 berikut ini menunjukkan hasil data pemeriksaan $\mathrm{Hb}$ pada ibu hamil TM II konsumsi tablet Fe dengan konsumsi telur ayam ras rebus. 
Tabel 1

Hasil Pemeriksaan Hb Ibu Hamil TM

II Konsumsi Tablet Fe dengan Konsumsi Telur Ayam Ras Rebus

\begin{tabular}{|c|c|c|c|}
\hline Kategori & Pre & Post & Perubahan $\mathrm{Hb}$ \\
\hline Mean & 12,013 & 13,740 & Naik : 14 \\
\hline SD & 1,0322 & 1,0176 & Turun: 1 \\
\hline
\end{tabular}
menunjukkan bahwa pada kelompok ibu hamil TM II hasil rata-rata pemeriksaan $\mathrm{Hb}$ sebelum mengkonsumsi tablet $\mathrm{Fe}$ dengan konsumsi telur ayam ras rebus yaitu $12,013 \pm 1,0322 \mathrm{gr} / \mathrm{dl}$ dan rata-rata setelah konsumsi tablet $\mathrm{Fe}$ dengan konsumsi telur ayam ras rebus yaitu $13,740 \pm 1,0176$. Sedangkan dilihat dari perubahan $\mathrm{Hb}$ sebelum dan sesudah mengkonsumsi tablet Fe pada kelompok ibu hamil dengan konsumsi telur ayam ras rebus terjadi peningkatan $\mathrm{Hb}$ sebanyak 14 responden dan penurunan sebanyak 1 responden.

Pada tabel 2 berikut ini menunjukkan hasil data pemeriksaan $\mathrm{Hb}$ pada ibu hamil TM II konsumsi tablet Fe tanpa konsumsi telur ayam ras rebus

Tabel 2

Hasil Pemeriksaan Hb Ibu Hamil TM II Konsumsi Tablet Fe tanpa Konsumsi Telur Ayam Ras Rebus

\begin{tabular}{|c|c|c|c|}
\hline Kategori & Pre & Post & $\begin{array}{c}\text { Perubahan } \\
\mathrm{Hb}\end{array}$ \\
\hline Mean & 12,633 & 12,413 & Naik: 7 \\
\hline SD & 1,0417 & 1,0419 & Turun: 8 \\
\hline
\end{tabular}

menunjukkan bahwa pada kelompok ibu hamil TM II hasil rata-rata pemeriksaan $\mathrm{Hb}$ sebelum mengkonsumsi tablet $\mathrm{Fe}$ tanpa konsumsi telur ayam ras rebus yaitu $12,633 \pm 1,0417 \mathrm{gr} / \mathrm{dl}$, dan rata-rata pemeriksaan $\mathrm{Hb}$ setelah mengkonsumsi tablet Fe tanpa konsumsi telur ayam ras rebus yaitu $12,413 \pm 1,0419$. Tabel tersebut juga menunjukkan perubahan $\mathrm{Hb}$ sebelum dan sesudah mengkonsumsi tablet $\mathrm{Fe}$ tanpa konsumsi telur ayam ras rebus pada ibu hamil TM II terjadi peningkatan $\mathrm{Hb}$ sebanyak 7 responden dan penurunan sebanyak 8 responden.

Hasil uji normalitas dengan uji Shapiro-Wilk dapat dilihat pada tabel 4.3 dibawah ini

Tabel 3

Hasil Uji Normalitas Data

\begin{tabular}{lrrrrrr}
\hline & \multicolumn{3}{c}{ Kolmogorov-Smirnov $^{\mathrm{a}}$} & \multicolumn{4}{c}{ Shapiro-Wilk } & Statistic & Df & Sig. & Statistic & Df & Sig. \\
\hline Hb Sebelum & .145 & 15 & .200 & .943 & 15 & .417 \\
Hb Sesudah & .145 & 15 & .200 & .942 & 15 & .407 \\
\hline
\end{tabular}

Dari tabel 3 hasil uji normalitas menunjukkan bahwa nilai probabilitas kadar hemoglobin sebelum konsumsi telur rebus sebesar 0,417 dan sesudah konsumsi telur rebus sebesar 0,407 keduanya lebih besar dari 0,05. Sehingga dapat disimpulkan bahwa distribusi data kadar hemoglobin baik sebelum dan sesudah konsumsi telur rebus telah memenuhi asumsi distrbusi normal.

\section{Tabel 4}

Hasil Uji Paired t-test

\begin{tabular}{lrcc}
\hline \multirow{2}{*}{ Kadar } & \multicolumn{3}{c}{ Perlakuan } \\
\cline { 2 - 4 } Hemoglobin & Mean & $\mathrm{T}$ & $\mathrm{P}$ \\
\hline Sebelum & 12,013 & & \\
& 13,740 & $-4,539$ & 0,000 \\
Sesudah & \multicolumn{3}{c}{ Kontrol } \\
\hline Kadar & \multicolumn{3}{c}{$\mathrm{T}$} \\
\cline { 2 - 4 } Hemoglobin & Mean & $\mathrm{P}$ \\
\hline Sebelum & 12,633 & & 0,559 \\
Sesudah & 12,413 & 0,599 &
\end{tabular}

Pada tabel 4 di atas diketahui ratarata (mean) kadar hemoglobin responden pada kelompok perlakuan sebelum konsumsi tablet $\mathrm{Fe}$ dengan konsumsi telur ayam ras rebus sebesar 12,013 gr\% dan rata-rata kadar hemoglobin responden setelah konsumsi tablet $\mathrm{Fe}$ dengan 
konsumsi telur ayam ras rebus sebesar $13,740 \mathrm{gr} \%$, berati ada perbedaan rata-rata 1,727 gr\% bahwa ada kenaikan rata-rata skor kadar hemoglobin responden sebesar 1.727 gr\%. Sedangkan rata-rata (mean) kadar hemoglobin responden pada kelompok kontrol sebelum konsumsi tablet Fe tanpa konsumsi telur ayam ras rebus sebesar 12,633 gr\% dan rata-rata kadar hemoglobin responden setelah konsumsi tablet $\mathrm{Fe}$ tanpa konsumsi telur ayam ras rebus sebesar $12,413 \mathrm{~g} \%$, terjadi penurunan rata-rata skor kadar hemoglobin sebesar 0,22 $\mathrm{g} \%$. Hal ini menunjukkan bahwa kadar hemoglobin responden setelah konsumsi tablet $\mathrm{Fe}$ dengan konsumsi telur ayam ras rebus mengalami peningkatan dibandingkan dengan konsumsi tablet $\mathrm{Fe}$ tanpa konsumsi telur ayam ras rebus.

Hasil analisis pada kelompok perlakuan diperoleh nilai probabilitas lebih kecil dari level of significant $5 \%$ $(0,000<0,05)$, maka dapat disimpulkan bahwa konsumsi tablet $\mathrm{Fe}$ dengan konsumsi telur ayam ras rebus berpengaruh signifikan terhadap peningkatan kadar hemoglobin pada ibu hamil. Sedangakan pada kelompok kontrol diperoleh nilai probabilitas lebih besar dari level of significant $5 \%$ $(0,559>0,05)$ maka dapat disimpulkan bahwa konsumsi tablet Fe tanpa konsumsi telur ayam ras rebus tidak signifikan terhadap peningkatan kadar hemoglobin pada ibu hamil.

\section{Tabel 5}

Perbedaan Hb pada ibu hamil TM II konsumsi tablet Fe dengan konsumsi telur ayam ras rebus dengan ibu hamil TM II konsumsi tablet Fe tanpa konsumsi telur ayam ras rebus

\begin{tabular}{llcc}
\hline No & $\begin{array}{l}\text { Hasil pemeriksaan } \\
\mathrm{Hb}\end{array}$ & Nilai $\mathrm{P}$ & $\mathrm{P}$ value \\
\hline 1 & Sebelum & $-1,637$ & 0,113 \\
2 & Setelah & 3,528 & 0,001 \\
3 & Perubahan & $-3,528$ & 0,001 \\
& kadar Hb & & \\
\hline
\end{tabular}

Dari hasil analisa data dengan uji independent sample t-test menunjukkan bahwa pada data pemeriksaan $\mathrm{Hb}$ pre (sebelum) mengkonsumsi tablet Fe antara kelompok dengan konsumsi telur ayam ras rebus dan Tanpa konsumsi telur ayam ras rebus menunjukkan nilai $p$ value 0,113 $(>0,05)$ yang berarti bahwa tidak terdapat perbedaan pada pemeriksaan $\mathrm{Hb}$ sebelum mengkonsusmsi tablet Fe antara kelompok dengan konsumsi telur ayam ras rebus dan Tanpa konsumsi telur ayam ras rebus.

Hasil Uji independent sample t-test pada data pemeriksaan $\mathrm{Hb}$ ibu hamil post (setelah) mengkonsumsi tablet Fe antara kelompok dengan konsumsi telur ayam ras rebus dan Tanpa konsumsi telur ayam ras rebus menunjukkan nilai $p$ value 0,001 $(<0,05)$. Dari hasil tersebut menunjukkan bahwa terdapat perbedaan hasil pemeriksaan $\mathrm{Hb}$ ibu hamil kelompok dengan konsumsi telur ayam ras rebus dan Tanpa konsumsi telur ayam ras rebus setelah mengkonsumsi tablet $\mathrm{Fe}$. Sedangkan hasil uji independent sample $t$ test pada perubahan $\mathrm{Hb}$ ibu hamil antara pre dan post konsumsi tablet Fe pada ibu hamil dengan konsumsi telur ayam ras rebus dan tanpa konsumsi telur ayam ras rebus menunjukkan $p$ value $0,001(<0,05)$, yang menunjukkan bahwa terdapat perbedaan antara perubahan $\mathrm{Hb}$ pre-post ibu hamil TM II konsumsi tablet Fe antara kelompok konsumsi telur ayam ras rebus dan tanpa konsumsi telur ayam ras rebus.

\section{PEMBAHASAN}

Hasil pengolahan data pada kelompok ibu hamil TM II hasil rata-rata 
pemeriksaan $\mathrm{Hb}$ sebelum mengkonsumsi tablet Fe dengan konsumsi telur ayam ras rebus yaitu $12,013 \pm 1,0322 \mathrm{gr} / \mathrm{dl}$ dan ratarata setelah konsumsi tablet $\mathrm{Fe}$ dengan konsumsi telur ayam ras rebus yaitu $13,740 \pm 1,0176$. Sedangkan dilihat dari perubahan $\mathrm{Hb}$ sebelum dan sesudah mengkonsumsi tablet Fe pada kelompok ibu hamil dengan konsumsi telur ayam ras rebus terjadi peningkatan $\mathrm{Hb}$ sebanyak 14 responden dan penurunan sebanyak 1 responden.

Hasil pengolahan data pemeriksaan $\mathrm{Hb}$ pada kelompok ibu hamil TM II hasil rata-rata pemeriksaan $\mathrm{Hb}$ sebelum mengkonsumsi tablet Fe tanpa konsumsi telur ayam ras rebus yaitu $12,633 \pm 1,0417 \mathrm{gr} / \mathrm{dl}$, dan rata-rata pemeriksaan $\mathrm{Hb}$ setelah mengkonsumsi tablet Fe tanpa konsumsi telur ayam ras rebus yaitu 12,413 $\pm 1,0419$. Pada pengolahan data juga menunjukkan perubahan $\mathrm{Hb}$ sebelum dan sesudah mengkonsumsi tablet Fe tanpa konsumsi telur ayam ras rebus pada ibu hamil TM II terjadi peningkatan $\mathrm{Hb}$ sebanyak 7 responden dan penurunan sebanyak 8 responden.

Dari hasil analisa data dengan uji paired t-test menunjukkan bahwa pada kelompok perlakuan diperoleh nilai probabilitas lebih kecil dari level of significant $5 \%(0,000<0,05)$, dapat disimpulkan bahwa konsumsi tablet $\mathrm{Fe}$ dengan konsumsi telur ayam ras rebus berpengaruh signifikan terhadap peningkatan kadar hemoglobin pada ibu hamil. Sedangkan pada kelompok kontrol diperoleh nilai probabilitas lebih besar dari level of significant $5 \%(0,559>0,05)$ maka dapat disimpulkan bahwa konsumsi tablet Fe tanpa konsumsi telur ayam ras rebus tidak signifikan terhadap peningkatan kadar hemoglobin pada ibu hamil TM II.

Hasil penelitian yang dilakukan pada kelompok kontrol sesuai dengan penelitian yang dilakukan oleh Fanny (2011), menyatakan bahwa tidak ada pengaruh pemberian tablet $\mathrm{Fe}$ dengan status antara kadar $\mathrm{Hb}$ awal dan $\mathrm{Hb}$ akhir $(p=0,563)>p=0.05)$ dan tidak sesuai dengan penelitian yang dilakukan oleh Yuswandari (2012), menyatakan bahwa ada pengaruh pemberian tablet besi $(\mathrm{Fe})$ terhadap penigkatan kadar hemonglobin pada ibu hamil trimester II dengan anemia diwilayah puskesmas Sidoharjo Kabupaten Sragen.

Hasil penelitian pada kelompok perlakuan sesuai dengan kesimpulan dari penelitian yang dilakukan oleh Fatimah (2011), menyatakan bahwa pola konsumsi ibu hamil berhubungan dengan rendahnya kadar hemoglobin ibu hamil di daerah penelitian. Disamping itu, konsumsi tablet Fe dan juga status gizi ibu hamil. Upaya peningkatan konsumsi ibu hamil harus terus dilakukan dengan menggunakan sumber bahan pangan lokal seperti ikan, telur, sayuran hijau (bayam, kangkung dan daun kelor), papaya pisang jeruk dan tomat. Selain itu, perhatian juga harus diberikan kepada status gizi ibu hamil dan konsumsi tablet besi sesuai dengan program yang ada di lapangan. Penelitian ini juga didukung dari penelitian yang dilakukan oleh Marlapan (2013), menyatakan bahwa ada hubungan status gizi dengan kejadian anemia pada ibu hamil di wilayah kerja Puskesmas Tuminting Kec. Tuminting Kota Manado.

Dari hasil analisa data dengan uji independent sample t-test menunjukkan bahwa pada data pemeriksaan $\mathrm{Hb}$ pre (sebelum) mengkonsumsi tablet Fe antara kelompok dengan konsumsi telur ayam 
ras rebus dan Tanpa konsumsi telur ayam ras rebus menunjukkan nilai $\mathrm{p}$ value 0,113 $(>0,05)$ yang berarti bahwa tidak terdapat perbedaan pada pemeriksaan $\mathrm{Hb}$ sebelum mengkonsusmsi tablet Fe antara kelompok dengan konsumsi telur ayam ras rebus dan Tanpa konsumsi telur ayam ras rebus. Hal ini dikarenakan pada ibu hamil TM II antara kelompok konsumsi tablet $\mathrm{Fe}$ dengan konsumsi telur ayam ras rebus dan Tanpa konsumsi telur ayam ras rebus sama-sama belum memasuki masa penelitian dan baru dimulai untuk mengkonsumsi tablet Fe dengan konsumsi telur ayam ras rebus dan tanpa konsumsi telur ayam ras rebus.

Hasil Uji independent sample t-test pada data pemeriksaan $\mathrm{Hb}$ ibu hamil post (setelah) mengkonsumsi tablet $\mathrm{Fe}$ antara kelompok dengan konsumsi telur ayam ras rebus dan Tanpa konsumsi telur ayam ras rebus menunjukkan nilai $\mathrm{p}$ value 0,001 $(<0,05)$. Dari hasil tersebut menunjukkan bahwa terdapat perbedaan hasil pemeriksaan $\mathrm{Hb}$ ibu hamil kelompok dengan konsumsi telur ayam ras rebus dan Tanpa konsumsi telur ayam ras rebus setelah mengkonsumsi tablet Fe. Pada kelompok ibu hamil konsumsi tablet $\mathrm{Fe}$ dengan konsumsi telur ayam ras rebus terjadi peningkatan rata-rata $\mathrm{Hb}$ dari sebelum dan sesudah yaitu $1,727 \mathrm{gr} / \mathrm{dl}$ (13,740-12,013). Sedangkan pada kelompok ibu hamil konsumsi tablet $\mathrm{Fe}$ tanpa konsumsi telur ayam ras rebus terjadi penurunan rata-rata $\mathrm{Hb}$ dari sebelum dan sesudah sebanyak $0,22 \mathrm{gr} / \mathrm{dl}$ $(12,633-12,413)$.

Hasil uji independent sample t-test pada perubahan kadar $\mathrm{Hb}$ ibu hamil antara pre dan post konsumsi tablet Fe pada ibu hamil dengan konsumsi telur ayam ras rebus dan tanpa konsumsi telur ayam ras rebus menunjukkan $\mathrm{p}$ value $0,001(<0,05)$, yang menunjukkan bahwa terdapat perbedaan antara perubahan $\mathrm{Hb}$ pre-post ibu hamil TM II konsumsi tablet Fe antara kelompok konsumsi telur ayam ras rebus dan tanpa konsumsi telur ayam ras rebus sehingga hipotesis dalam penelitian ini diterima.

Kandungan gizi telur kaya akan protein yang bermutu tinggi. Rata-rata kadar protein telur adalah 12-16\% atau sekitar 7-8 gram protein dalam satu butir telur yang cukup besar. di dalam telur juga ada kandungan sejenis mineral mikro yang sangat penting, yaitu zat besi, seng, dan selenium. Telur mengandung zat besi yang cukup baik. Kandungan besi telur adalah 1,04 mg pada telur utuh dan 0,95 mg pada kuning telur. Sementara itu, kandungan zat seng pada telur adalah sebesar 0,72 $\mathrm{mg}$ telur utuh dan 0,58 $\mathrm{mg}$ kuning telur (Anwar dan Khomsan, 2009). Sehingga dengan konsumsi telur ayam ras rebus efektif untuk peningkatan kadar $\mathrm{Hb}$ pada ibu hamil trimester II.

\section{KESIMPULAN DAN SARAN}

Berdasarkan hasil analisis data dan tujuan dalam penelitian ini, dapat disimpulkan. Pada kelompok ibu hamil konsumsi tablet Fe dengan konsumsi telur ayam ras rebus terjadi peningkatan ratarata $\mathrm{Hb}$ dari sebelum dan sesudah yaitu $1,727 \mathrm{gr} / \mathrm{dl} \quad(13,740-12,013)$. Pada kelompok ibu hamil konsumsi tablet $\mathrm{Fe}$ tanpa konsumsi telur ayam ras rebus terjadi penurunan rata-rata $\mathrm{Hb}$ dari sebelum dan sesudah sebanyak $0,22 \mathrm{gr} / \mathrm{dl}$ $(12,633$ - 12,413). Terdapat perubahan $\mathrm{Hb}$ ibu hamil antara pre dan post konsumsi tablet Fe pada ibu hamil dengan konsumsi telur ayam ras rebus dan tanpa konsumsi telur ayam ras rebus menunjukkan $\mathrm{p}$ value $0,001(<0,05)$, yang menunjukkan perbedaan antara perubahan 
$\mathrm{Hb}$ pre-post ibu hamil TM II konsumsi tablet $\mathrm{Fe}$ antara kelompok konsumsi telur ayam ras rebus dan tanpa konsumsi telur ayam ras rebus. Sehingga konsumsi telur ayam ras rebus efektif untuk peningkatan kadar $\mathrm{Hb}$ pada ibu hamil trimester II di wilayah kerja Puskesmas Klaten Tengah.

Berdasarkan pelaksanaan dan hasil penelitian, saran yang dapat diberikan adalah bagi Ibu Hamil di Wilayah Kerja Puskesmas Klaten Tengah. Disarankan agar ibu hamil mengkonsumsi telur ayam ras rebus untuk membantu memperbaiki status gizi ibu hamil khususnya dalam pencegahan anemia pada ibu hamil. Dengan adanya penelitian ini diharapkan pihak Puskesmas dapat memberikan informasi kepada ibu hamil untuk mengkonsumsi telur ayam ras rebus sebagai upaya untuk mencegah anemia pada kehamilan. Diharapkan hasil penelitian ini dapat digunakan sebagai bahan informasi untuk disampaikan kepada para ibu hamil Trimester II diwilayah kerjanya.

\section{DAFTAR RUJUKAN}

Anwar, F dan Khomsan, A. 2008. Sehat itu Mudah Wujudkan Hidup Sehat dengan Makanan Tepat. Jakarta Selatan : Mizon Publika

Fanny, L. 2011. Pengaruh Pemberian Tablet Fe Terhadap Kadar Hemoglobin Ibu Hamil di Puskesmas Tamamaung Tahun 2011. Media Gizi Pangan, Vol. XIII, Edisi 1, 2001. http://jurnalmediagizipangan.files. wordpress.com/2012/07/pengaruhpemberian-tablet-fe-terhadapkadar-hemoglobin-ibu-hamil.pdf. diakses pada tanggal 24 Februari 2014
Fatimah, St. 2011. Pola Konsumsi dan Kadar Hemoglobin pada Ibu Hami di Kabupaten Maros Sulawasi Selatan. Makara, Kesehatan, Vol. 15, No. 1, Juni 2011: 31-36. http://journal.ui.ac.id/health/article /download/795/757 diakses pada tanggal 23 September 2013

Hidayat, A. 2011. Penelitian Kebidanan dan Teknik Analisa Data. Jakarta: Salemba Medika

Marlapan, S. 2013. Hubungan Status Gizi dengan Kejadian Anemia pada Ibu Hamil di Wilayah Kerja Puskesmas Tuminting Kec. Tuminting Kota Manado. ejournal keperawatan (e-Kp) Volume 1. Nomor 1. Agustus 2013. http://ejournal.unsrat.ac.id/index.p hp/jkp/article/download/2232/1789 diakses pada tanggal 23 September 2013

Notoatmodjo, S. 2010. Metodologi Penelitian Kesehatan. Jakarta: PT Rineka Cipta

Yuswandari. 2012. Pengaruh Pemberian Tablet Besi (Fe) Terhadap Peningkatan Kadar Hemoglobin pada Ibu Hamil Trimester II dengan Anemia di Wilayah Puskesmas Sidoharjo Kabupaten Sragen. Poltekkes Surakarta. Skripsi 